\title{
Isolation of 10 tetranucleotide microsatellite loci in the blackcap (Sylvia atricapilla)
}

\author{
GERNOT SEGELBACHER , *GREGOR ROLSHAUSEN,†TANJA WEIS-DOOTZ , ${ }^{*}$ AVID SERRANO \\ H. MARTIN SCHAEFER† \\ *Department of Wildlife Ecology and Management, University Freiburg, Tennenbacher Str. 4, D-79106 Freiburg, Germany, \\ †Department of Evolutionary Biology and Animal Ecology, Faculty of Biology, University Freiburg, Hauptstrasse 1, D-79108 Freiburg, \\ Germany, łEstación Biológica de Doñana (CSIC), Pabellón del Perú, Avda. Maria Luisa s/n, 41013 Sevilla, Spain
}

\begin{abstract}
We isolated 10 polymorphic microsatellite DNA loci from the blackcap (Sylvia atricapilla) and optimized them for future studies of population differentiation in populations with different migration strategies in southwestern Germany. The loci were screened for polymorphism using 178 individuals from two populations in Germany and Spain. The primers amplified highly variable loci characterized by two to 19 alleles per locus and their observed and expected heterozygosities range from 0.47 to 0.81 and from 0.50 to 0.91 , respectively.
\end{abstract}

Keywords: primer, Sylvia atricapilla, tetranucleotide microsatellites

The blackcap (Sylvia atricapilla) is an abundant Eurasian passerine and a model species for studying avian biology and the evolution of migratory behaviour (Helbig 1996; Berthold 1998; Coppack et al. 2001). Blackcaps exhibit a wide diversity of migratory strategies including nonmigratory populations, partial migrants and populations with different migratory orientation and distances. Because the entire range from sedentariness to long-distance migration can be found within a single species, this species illustrates the flexibility of migratory behaviour in an evolutionary sense.

Apart from studies demonstrating differences in migratory behaviour, the genetic diversification of migration patterns has also been studied (Perez-Tris et al. 2004). With regard to breeding areas, the species is currently divided into five subspecies which show differences in physiology, morphology and life-history traits (Shirihai et al. 2001; Fiedler 2005). Particularly interesting is the recent rapid microevolution of a new migratory direction within the blackcap in west-central Europe (Berthold et al. 1992). The

Correspondence: Dr Gernot Segelbacher, Fax: +49 761203 3667; E-mail: gernot.segelbacher@wildlife.uni-freiburg.de proportion of birds migrating with northwestern direction, wintering in Britain, has increased from $0 \%$ to $10-15 \%$ in the last 50 years. This change in migratory direction has a genetic basis (Berthold et al. 1992). Assortative mating driven by differential arrival times in spring may lead to an increasing isolation of populations wintering in Britain and in the Mediterranean (Bearhop et al. 2005). The blackcap is therefore a model system to investigate the genetic structure of different populations to study microevolutionary processes leading to different migratory strategies in avian species.

Microsatellites were isolated using magnetic bead capture enrichment (Glenn \& Schable 2005) from the genomic DNA of 178 individuals. A genomic library was made after double enrichments for the motifs $(\mathrm{AACT})_{8}(\mathrm{AAGT})_{8}$ $(\mathrm{ACAT})_{8}$ and $(\mathrm{AGAT})_{8}$. Total DNA was digested with RsaI (New England Biolabs), and fragments were ligated to doublestranded SuperSNX24 linkers. Fragments were hybridized to biotinylated oligonucleotides and captured with magnetic streptavidin beads (Invitrogen). Enriched DNA was amplified using the polymerase chain reaction (PCR) primer forward SuperSNX24. Cloning was conducted using TOPO-TA Cloning Kit (Invitrogen). Clones with 
inserts between 300-bp and 700-bp length were purified using QIAquick PCR Purification Kit (QIAGEN) and sequenced. Sequences from both strands were assembled and edited in bioedit (Hall 1999) and microsatellites located using tandemrepeatsfinder (http:/tandem.bu.edu $/$ trf/trf.html) and confirmed by eye. Primers were designed from the flanking sequences of the tandem repeats using primer 3 software. Twenty-one out of the 32 sequenced clones contained microsatellites. Eighteen PCR primers were designed using primer 3 (http:/frodo.wi.mit.edu/ primer3/input.htm) and were tested for amplification on $1.2 \%$ agarose gels. Ten of the tested primer pairs amplified high-quality PCR products that showed polymorphism across 10 selected individuals and were further genotyped in a larger sample.

We caught 118 birds at Radolfzell $\left(47^{\circ} \mathrm{N}, 8^{\circ} \mathrm{E}\right)$, southwestern Germany, during spring 2006 and 60 individuals in Southern Spain $\left(37^{\circ} \mathrm{N}, 5^{\circ} \mathrm{W}\right)$. Genomic DNA was extracted from blood samples using the DNeasy Blood and Tissue Kit (QIAGEN). PCR amplifications were performed in a $10-\mu \mathrm{L}$ volume consisting of $1 \times$ QIAGEN PCR buffer (contains Tris-Cl, $\mathrm{KCl}$ and $\left(\mathrm{NH}_{4}\right)_{2} \mathrm{SO}_{4}$ at unspecified concentrations), $0.025 \mathrm{~mm}$ of each primer, $3 \mathrm{~mm} \mathrm{MgCl}_{2}, 0.40 \mathrm{~mm}$ of each dNTP and 0.5 U Taq DNA Polymerase(QIAGEN) and 1- $\mu \mathrm{L}$ template using an Eppendorf Mastercycler Gradient. A Touchdown thermal cycling programme encompassing a $10^{\circ} \mathrm{C}$ span of annealing temperatures ranging between
$60{ }^{\circ} \mathrm{C}$ and $50^{\circ} \mathrm{C}$ was used for the amplification. Following an initial denaturation step of $95^{\circ} \mathrm{C}$ for $3 \mathrm{~min}$, cycling parameters were 20 cycles at $95{ }^{\circ} \mathrm{C}$ for $30 \mathrm{~s}, 60^{\circ}$ annealing temperature (decreased $0.5{ }^{\circ} \mathrm{C}$ per cycle) for $30 \mathrm{~s}$ and $72{ }^{\circ} \mathrm{C}$ for $40 \mathrm{~s}$ and 15 cycles of $95^{\circ} \mathrm{C}$ for $30 \mathrm{~s}, 50^{\circ} \mathrm{C}$ for $30 \mathrm{~s}$ and $72{ }^{\circ} \mathrm{C}$ for $40 \mathrm{~s}$ and a final extension step of $72{ }^{\circ} \mathrm{C}$ for $5 \mathrm{~min}$. PCR products were run on Elchrom Spreadex EL 400 gels run in an Elchrom SEA 2000 apparatus and sized with M3 size standard (Elchrom, Switzerland).

Each locus was tested for polymorphism and heterozygosity using 178 individuals from two different locations (Spain, Western Germany). Characteristics of the 10 working primer pairs are given in Table 1 . We estimated the number of alleles per locus, observed and expected heterozygosity, polymorphic information content and frequency of null alleles and tested for deviations from Hardy-Weinbergequilibrirum using cervus version 3.0 (Marshall et al. 1998). Loci syl3, syl4 and syl10 deviated significantly from HWE only when all samples were analysed, but not when each population was analysed alone. No linkage was detected among all 45 paired loci comparisons $(P<0.05$; genepop version 3.4, Raymond \& Rousset 1995).

Overall the high numbers of alleles per locus, high PIC values and heterozygosity and paternity exclusion probabilities of 0.99 demonstrate the potential of the blackcap microsatellite primers for a variety of questions like kinship analysis and population differentiation.

Table 1 Microsatellite loci in Sylvia atricapilla including GenBank Accession number, primer sequence, repeat motif, size of cloned allele in base pair, number of alleles $(k) ; H_{\mathrm{E}}$, expected heterozygosity; $H_{\mathrm{O}}$, observed heterozygosity; and PIC, polymorphic information content and frequency of null alleles

\begin{tabular}{|c|c|c|c|c|c|c|c|}
\hline $\begin{array}{l}\text { Locus accession } \\
\text { number }\end{array}$ & Primer sequence (5'-3') & Repeat motif & Size (bp) & $k$ & $H_{\mathrm{E}}\left(H_{\mathrm{O}}\right)$ & PIC & $\begin{array}{l}\text { Null allele } \\
\text { frequency }\end{array}$ \\
\hline Syl1 & TTGCTTTTGGCAAAGATATAGATG & $(\text { GATA })_{14}$ & 150 & 13 & $0.86(0.73)$ & 0.841 & 0.08 \\
\hline EU304338 & CCTGGGTTGTTTTACCAGATTC & & & & & & \\
\hline Syl2 & GTCCCACTAATGGGTTTTCC & $(\mathrm{CTAT})_{7}$ & 158 & 12 & $0.86(0.81)$ & 0.837 & 0.03 \\
\hline EU304344 & GTTGTCAGAATTCAACTACTTACTGC & CGATCTAAT(CTAT) $)_{5}$ & & & & & \\
\hline Syl3 & CACGTTACCGTCTTTATATTCCATC & $(\mathrm{GATA})_{2}(\mathrm{GAGA})_{3} \mathrm{GATA}$ & 197 & 6 & $0.66(0.52)^{*}$ & 0.603 & 0.11 \\
\hline EU304336 & TTTTTCACATGGGTGCAGTC & GAGG $(\mathrm{GATA})_{2}(\mathrm{GACA})_{3} \mathrm{GATA}$ & & & & & \\
\hline Syl4 & ACCCATATGGAATAAATTGTGG & $(\mathrm{GTAT})_{10}$ & 200 & 14 & $0.87(0.49)^{*}$ & 0.849 & 0.28 \\
\hline EU304337 & GAGCTGGCAGGGAATATTTG & $(\mathrm{CTAT})_{12}$ & & & & & \\
\hline Syl5 & САAАAATTTGGTATAAACTTCСAAC & $(\mathrm{CTAT})_{3} \mathrm{AT}(\mathrm{CTAT})_{14}$ & 195 & 15 & $0.89(0.54)$ & 0.887 & 0.24 \\
\hline EU304341 & GCCCTTGAAAAACAAACACC & & & & & & \\
\hline Syl6 & TCAGCAGCAACAAGATGAGC & GATACATA $(\text { GATA })_{10}$ & 192 & 19 & $0.89(0.64)$ & 0.878 & 0.16 \\
\hline EU304342 & GGAACTTGCAAACTGTGAATTG & GAAA(GATA $)_{3}$ & & & & & \\
\hline Syl7 & СTTGTTCTTTCTTCTGCATTGG & GATAGATTTA & 189 & 2 & $0.50(0.47)$ & 0.375 & 0.03 \\
\hline EU304339 & GGAGTTTTGGCTTTTGTTGG & $(\text { GATA })_{2}$ GATGTA $(\text { GATA })_{2}$ & & & & & \\
\hline Syl8 & САATGCССАТСТАСССАТСТ & $(\text { CTAT })_{2}(\text { GTATCTAT })_{2}$ & 193 & 17 & $0.91(0.48)$ & 0.897 & 0.31 \\
\hline EU304340 & TTTCTAAATATGCACAGGTGCTG & $(\mathrm{CTAT})_{2}(\mathrm{GTATCTAT})_{2}(\mathrm{CTAT})_{9}$ & & & & & \\
\hline Syl9 & AGGCATTTAAAGAAGGCAGTG & $(\mathrm{CTAT})_{12}$ & 190 & 17 & $0.77(0.65)$ & 0.749 & 0.08 \\
\hline EU304343 & GCCAAGAAAGAGGGAGGTTC & & & & & & \\
\hline Syl10 & TCTTCAGAGGTGAAGGTGTGC & $(\text { CTAT })_{11}$ & 185 & 13 & $0.85(0.49)^{*}$ & 0.833 & 0.27 \\
\hline EU304345 & GCTGGGGAGTGTAAAAGTGG & & & & & & \\
\hline
\end{tabular}




\section{Acknowledgements}

This project was supported by the Wissenschaftliche Gesellschaft Freiburg. Jaime Garcia-Moreno provided further support.

\section{References}

Bearhop S, Fiedler W, Furness RW et al. (2005) Assortative mating as a mechanism for rapid evolution of a migratory divide. Science, 310, 502-504.

Berthold P (1998) Bird migration: genetic programs with high adaptability. Zoology-Analysis of Complex Systems, 101, 235-245.

Berthold P, Helbig AJ, Mohr G, Querner U (1992) Rapid microevolution of migratory behaviour in a wild bird species. Nature, 360, 669-670.

Coppack T, Pulido F, Berthold P (2001) Photoperiodic response to early hatching in a migratory bird species. Oecologia, 128, 181-186.

Fiedler W (2005) Ecomorphology of the external flight apparatus of blackcaps (Sylvia atricapilla) with different migration behavior. Annals of the New York Academy of Sciences, 1046, 253-263.
Glenn TC, Schable NA (2005) Isolating microsatellites DNA loci. Methods in Enzymology, 395, 202-222.

Hall TA (1999) bioedit: a user friendly biological sequence alignment editor and analysis program for Windows 95/98/NT. Nucleic Acids Symposium Series, 41, 95-98.

Helbig AJ (1996) Genetic basis, mode of inheritance and evolutionary changes of migratory directions in palearctic warblers (Aves: Sylviidae). Journal of Experimental Biology, 199, 49-55.

Marshall TC, Slate J, Kruuk L, Pemberton JM (1998) Statistical confidence for likelihood-based paternity inference in natural populations. Molecular Ecology, 7, 639-655.

Perez-Tris J, Bensch S, Carbonell R, Helbig AJ, Telleria JL (2004) Historical diversification of migration patterns in a passerine bird. Evolution, 58, 1819-1832.

Raymond M, Rousset F (1995) genepop (version 1.2): population genetics software for exact tests and ecumenicism. Journal of Heredity, 86, 248-249.

Shirihai H, Gargallo G, Helbig AJ (2001) Sylvia warblers. In: Identification, Taxonomy and Phylogeny of the Genus (eds Kirwan GM, Svensson L.). Princeton University Press. 